Tropical Journal of Pharmaceutical Research, February 2009; 8 (1): 19-26

(C) Pharmacotherapy Group,

Faculty of Pharmacy, University of Benin,

Benin City, 300001 Nigeria.

All rights reserved.

Research Article

Available online at http://www.tjpr.org

\title{
Protective effect of methanol-methylene chloride extract of Terminalia glaucescens leaves on streptozotocin-induced diabetes in mice
}

\author{
Guy BSN Njomen ${ }^{1}$, René Kamgang ${ }^{1 *}$, Petit RN Soua ${ }^{1}$, Jean LE \\ Oyono $^{2}$, Njifutie Njikam ${ }^{1}$ \\ ${ }^{1}$ General Endocrinology and Metabolism Systems (GEMS), Laboratory of Animal Physiology, Faculty of Sciences, \\ University of Yaounde 1, Cameroon, ${ }^{2}$ Faculty of Medicine and Biomedical Sciences, University of Yaounde 1 and \\ IMPM - Yaounde, Cameroon
}

\begin{abstract}
Purpose: Terminalia glaucescens (Combretaceae) is traditionally used in Cameroon in the treatment of diabetes. The anti-hyperglycemic effect of the methanol-methylene chloride extract of the leaves of this plant was investigated in streptozotocin (STZ)-induced diabetic mice.

Methods: Diabetes was induced in mice by a daily dose of STZ $\left(45 \mathrm{mg} \mathrm{kg}^{-1}\right.$ body weight i.p.) for 5 days. From one day before STZ injection, normal and diabetic-test mice received one oral dose of the extract (100 mg kg-1 or $300 \mathrm{mg} \mathrm{kg}^{-1}$ body weight) daily for 15 days. The effect of the extract on body weight gain, food and water intake, plasma metabolites (glucose and lipids) and insulin levels was investigated. Results: Diabetic control mice and diabetic mice pre-treated with $100 \mathrm{mg} \mathrm{kg}^{-1}$ extract showed body weight loss, marked $(P<0.001)$ polyphagia and polydipsia, high plasma metabolites and glucose $\left(P_{<}\right.$ $0.001)$, non-esterified fatty acids (NEFA) $(P<0.05)$, triglycerides $(T G)(P<0.05)$, and cholesterol $(P<$ $0.05)$ and low insulin $(P<0.001)$ levels. Normal control, i.e., normal treated mice and $300 \mathrm{mg} \mathrm{kg}^{-1}$ extract pre-treated diabetic mice, presented normal weight gain, normal food and water intake, normal plasma metabolites and insulin levels, and did not exhibit very significant changes $(P<0.1)$ in blood glucose level..

Conclusion: These results indicate that the extract of $T$. glaucescens leaf at a dose of $300 \mathrm{mg} \mathrm{kg}$ protects against STZ-induced diabetic effects and could explain the traditional use of this plant in the management of diabetes.
\end{abstract}

Keywords: Terminalia glaucescens, streptozotocin, diabetes mellitus, glycemia, lipemia.

*Corresponding author: E-mail:gemskruy@yahoo.fr 


\section{INTRODUCTION}

Diabetes mellitus is a metabolic disorder characterized by fasting hyperglycemia and alterations in carbohydrate, fat and protein metabolism, associated with absolute or relative deficiencies in insulin secretion and/or insulin action ${ }^{1}$. As the number of people with diabetes multiplies worldwide, the disease has taken an ever-increasing share of national and international health budgets. Type 1 diabetes is an auto-immune disease characterized by a local inflammatory reaction in and around pancreatic islets that is followed by selective destruction of insulin-secreting $\square$ cells $^{2-4}$. Experimentally, streptozotocin (STZ) or alloxan are used to induce diabetes in rodents. STZ is effective in triggering islet cell death by acute oxidative stress. STZ-induced diabetic mice are one of the animal models of insulin-dependent diabetes mellitus characterized by high fasting blood glucose levels and drastic reduction in plasma insulin concentration ${ }^{5}$.

Though different types of oral hypoglycemic agents are available along with insulin for the management of diabetes mellitus, there is a growing interest in herbal remedies due to the side effects associated with orthodox therapeutic agents ${ }^{6,7}$. Furthermore, plants have played a major role in the discovery of new therapeutic agents. A medicinal plant, Galega officinalis, led to the discovery and synthesis of metformin; however, there is still a need for new oral antidiabetic drugs with minimal side effects ${ }^{8,9}$.

The available literature shows that there are more than 400 plant species showing antidiabetic activities $^{10-12}$. The protective effect of some plants or natural substances against the death of $\square$ cells has been reported ${ }^{13}$. Information provided by practitioners of traditional medicine in the Centre Province of Cameroon suggests that Terminalia glaucescens possesses useful anti-diabetic properties, although this was not cited in the national ethnobotanical survey of Cameroonian medicinal plants. Terminalia arjuna, Terminalia belerica, Terminalia chebula, Terminalia catappa and Terminalia pallida are other species of the same family (Combretaceae) known for their antidiabetic properties ${ }^{1}$.

The present study was undertaken to investigate the anti-hyperglycemia effect of the methanol/methylene chloride extract of Terminalia glaucescens leaf on the hyperglycemia induced by a multiple dose of STZ in diabetic mice.

\section{MATERIALS AND METHODS}

\section{Plant extract}

Fresh leaves of Terminalia glaucescens were harvested in October 2005 in Mbalmayo in the Centre Province of Cameroon. T. glaucescens was identified by $\mathrm{Dr}$ Simeon Tchoulagueu of the Teachers' Training College of the University of Yaoundé I, who kept a voucher specimen (no. 4016/BS) in the laboratory. Two kilograms of the sun-dried powdered leaves were macerated in a mixture of methanol/methylene chloride (1:1) for 7 days (with occasional stirring) at room temperature. The mixture was filtered with Whatman No.1 filter paper and the filtrate concentrated in a rotary evaporator (Rotavapor) at $45^{\circ} \mathrm{C}$ to yield $125 \mathrm{~g}$ of a dry dark extract. Doses of $20 \mathrm{mg}$ $\mathrm{mL}^{-1}$ and $60 \mathrm{mg} \mathrm{mL}^{-1}$ were obtained by dissolving $2 \mathrm{~g}$ and $6 \mathrm{~g}$, respectively, of the concentrated extract in $100 \mathrm{~mL}$ of $10 \%$ dimethyl sulfoxide (DMSO) solution. The experimental dose was $5 \mu \mathrm{L} \mathrm{g}^{-1}$ body weight.

\section{Experimental animals}

Male albino Wistar mice (26-30 g weight, 8-10 weeks old) were raised in the animal house of our laboratory under natural conditions with free access to water and regular rodent chow. For this experiment, the mice were fasted overnight prior to blood sugar determination and randomly divided into 6 groups of 8 animals each as follows: 
- One group of mice (control, NC) received $10 \%$ DMSO p.o. and citrate buffer $(\mathrm{Cb})$ i.p.,

- Two groups of normal mice (NE) were treated with $100 \mathrm{mg} \mathrm{kg}^{-1}$ body weight (NE100) or $300 \mathrm{mg} \mathrm{kg}^{-1}$ body weight (NE300) plant extract (p.o.) and Cb (i.p.),

- One group of diabetic mice (diabetic control, DC) was treated with DMSO and STZ,

- Two groups of diabetic mice (DE) were treated with $100 \mathrm{mg} \mathrm{kg}^{-1}$ (DE100) or 300 $\mathrm{mg} \mathrm{kg}^{-1}$ (DE300) body weight plant extract and STZ.

To induce diabetes, the mice received $45 \mathrm{mg}$ $\mathrm{kg}^{-1}$ (i.p.) of freshly prepared STZ (Sigma Aldrich No. SO 130) dissolved in citrate buffer $100 \mathrm{mM} \mathrm{pH} 4.5(\mathrm{Cb})$ daily for five consecutive days. The plant extract was administered to the fed mice and STZ injection was preceded by $4 \mathrm{~h}$ of fasting. Animals DE100 and DE300 orally received a dose of plant extract, daily for five consecutive days, followed 6 hours later by i.p. injection of STZ. T. glaucescens extract administration began one day (day 0 ) before the beginning of STZ injection and continued for up to day 14

Animal housing and in vivo experiments conformed to the guidelines of the European Union on Animal Care (CEE Council 86/609) and were ethically approved by the Institutional Committee of the Ministry of Scientific Research and Innovation of Cameroon.

\section{Measurement of body weight gain, food and water intake}

Food and water intake were monitored on days $1,3,6$ and 12 while body weight was measured on days $0,3,6,9,12$ and 15 .

\section{Determination of blood parameters}

Blood samples for glucose determination were obtained from the tail tip of $4 \mathrm{~h}$ fasted mice on days 0,6 and 12 of the experiment. Blood glucose level was estimated using a glucometer (Accu-Check, Roche). Mice with fasting blood glucose $\geq 14 \mathrm{mM}$ were considered as diabetic ${ }^{14}$.

At the end of the treatment (day 15), mice were weighed and anesthetized with sodium pentobarbital (60 $\mathrm{mg} \mathrm{kg}^{-1}$ i.p.). Blood was rapidly collected by cardiac puncture in syringes containing EDTA. Blood samples were centrifuged (1 min, $8000 \mathrm{~g}$ ), from which plasma was collected, aliquoted and snapfrozen in liquid nitrogen. Plasma parameters were assayed using commercially available kits according to the manufacturers' instructions: triglycerides (TG: Triglycerides PAP, bioMérieux, Marcy l'Etoile, France), non esterified fatty acids (NEFA, NEFA-C, Wako), and cholesterol (RTU, bioMérieux). Plasma insulin levels were measured by radioimmunoassay using porcine insulin kit (SB-insulin-CT, CIS Biointernational, Gif-surYvette, France) with guinea pig anti-porcine insulin serum-coated tubes.

\section{Statistical analysis}

The results are expressed as mean $\bar{X} \pm$ standard error of mean (S.E.M.). Mean values were obtained by one-way analysis of variance (ANOVA) using the computer software, StatView 4.5, followed by Dunnets multiple comparison test. The significance of difference between and within various groups was determined. Values of $\mathrm{P}<0.05$ were taken to imply statistical significance.

\section{RESULTS}

\section{Body weight, food and water intake}

There was no significant difference in body weight between the groups prior to STZ injection. The body weight progressively decreased in diabetic control group (DC) and diabetic group treated with $100 \mathrm{mg} \mathrm{kg}^{-1}$ body weight extract (DE100). The decrease was significant on days $6(P<0.05)$, and 9 and 15 $(\mathrm{P}<0.001)$ compared to the normal control group (-28\% DC and - 25\% DE100) as shown in Fig 1. Body weight gain for normal control (NC), normal treated (NE100 and NE300) and 
$300 \mathrm{mg} \mathrm{kg}^{-1}$ treated diabetic (DE300) mice increased progressively and were comparable. Furthermore, DC and DE100 presented significant $(P<0.01)$ increases in food and water intake on day 3 which became more marked on the 12th day, whereas other groups (NC, E100; E300 and DE300) did not exhibit significant variations in food and water intake (Fig 2).

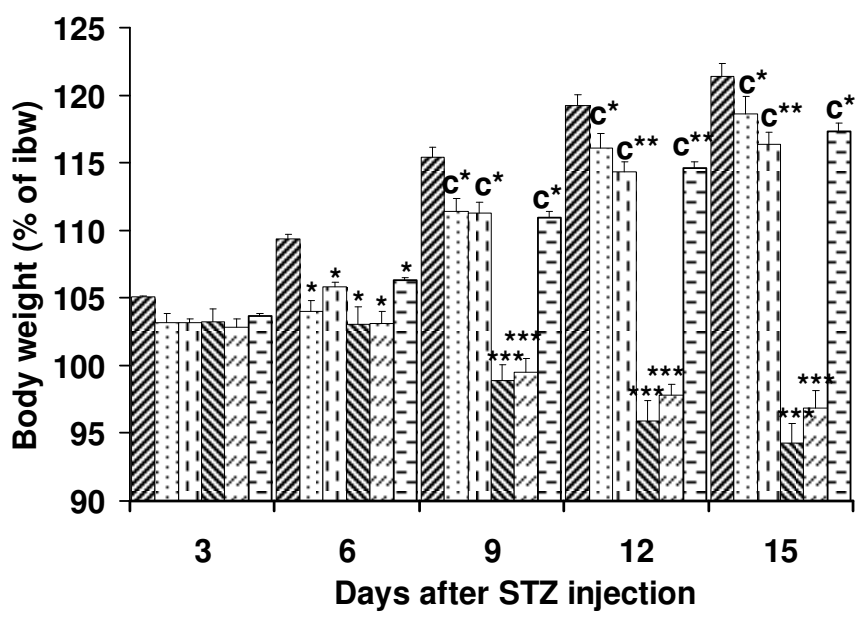

Figure 1: Body weight of mice (expressed as $\%$ of initial body weight ibw $=100 \%$ ) within 15 days of treatment with the extract of Terminalia glaucescens leaf. Key: Normal mice treated with $100 \mathrm{mg} \mathrm{kg}^{-1}$ (泪) and $300 \mathrm{mg} \mathrm{kg}^{-1}$ (罗) body weight, diabetic mice pre-treated with $100 \mathrm{mg} \mathrm{kg}^{-1}$

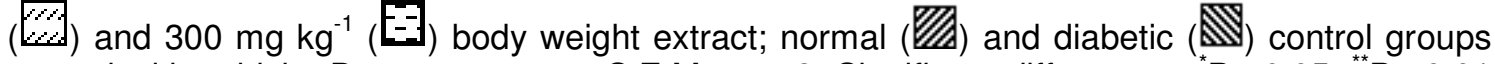
treated with vehicle. Data are mean \pm S.E.M., $n=8$. Significant differences: ${ }^{*} P<0.05,{ }^{* *} P<0.01$ and ${ }^{* \star *} \mathrm{P}<0.001$ compared with $\mathrm{NC}$ value; ${ }^{\mathrm{C}} \mathrm{P}<0.001$ compared with $\mathrm{DC}$ value.
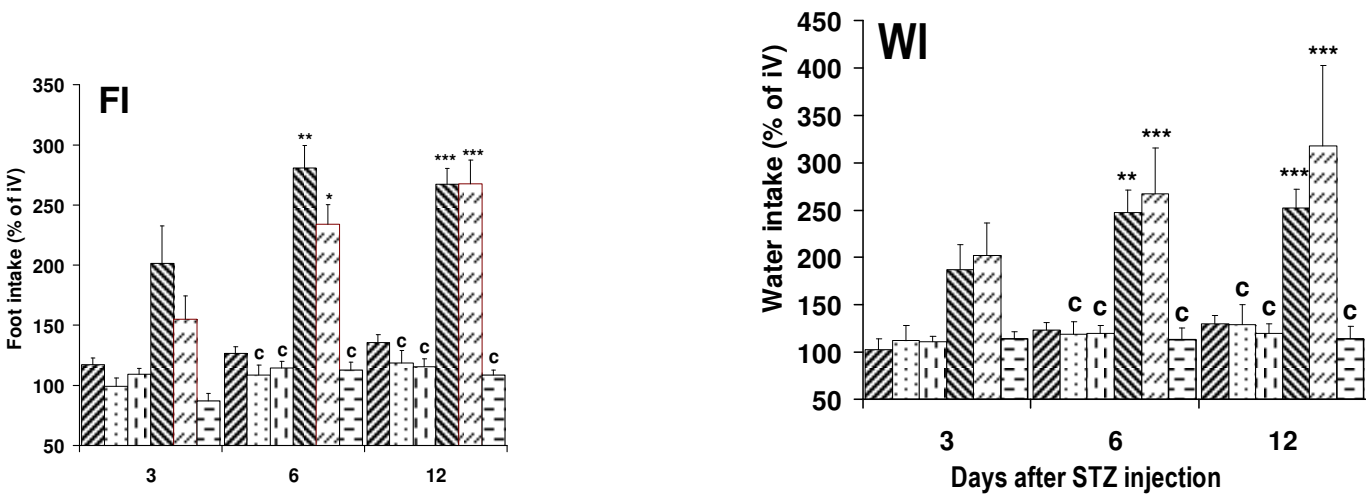

Figure 2: Variations of mice food $(\mathrm{FI})$ and water $(\mathrm{WI})$ intake (expressed as \% of initial values $=100 \%$ ) within 12 days of treatment with Terminalia glaucescens leaf extract. Key: Normal mice treated with $100 \mathrm{mg} \mathrm{kg}^{-1}$ (是) and $300 \mathrm{mg} \mathrm{kg}^{-1}$ (圆) body weight, diabetic-test mice pre-treated with $100 \mathrm{mg} \mathrm{kg}^{-1}$ ( $\left.2 / 2\right)$ and $300 \mathrm{mg} \mathrm{kg}^{-1}$ (E- extract;

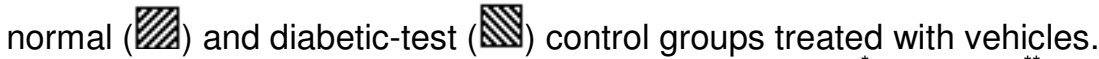

Data are mean \pm S.E.M., $n=8$. Significant differences: ${ }^{*} \mathrm{P}<0.05,{ }^{* *} \mathrm{P}<0.01$ and ${ }^{* * *} \mathrm{P}<$ 0.001 compared with $\mathrm{NC}$ values; ${ }^{\mathrm{C}} \mathrm{P}<0.001$ compared with $\mathrm{DC}$ values. 


\section{Plasma metabolites and insulin levels}

STZ administration significantly $(P<0.001)$ reduced insulin plasma levels (Fig. 3). $T$. glaucescens at $100 \mathrm{mg} \mathrm{kg}^{-1}$ did not prevent the decrease of the plasma insulin level. The plant extract also did not significantly change the insulin level in normal mice (NE100 and NE300). STZ did not modify insulin secretion in mice treated with $300 \mathrm{mg} \mathrm{kg}^{-1}$ extract. In DC mice, the observed reduction of insulin secretion was accompanied by a significant $(\mathrm{P}<0.05)$ increase in all plasma lipids: $+45 \%$ TG, $+32 \%$ NEFA, $+29 \%$ cholesterol (Table 1). T. glaucescens extract reduced the STZinduced elevation of plasma lipids in a dosedependent manner. Blood glucose level in DC mice was very significantly $(P<0.001)$ increased on the 6th day and beyond (Fig. 4). The dose of $100 \mathrm{mg} \mathrm{kg}^{-1}$ body weight of the extract did not show a marked protective

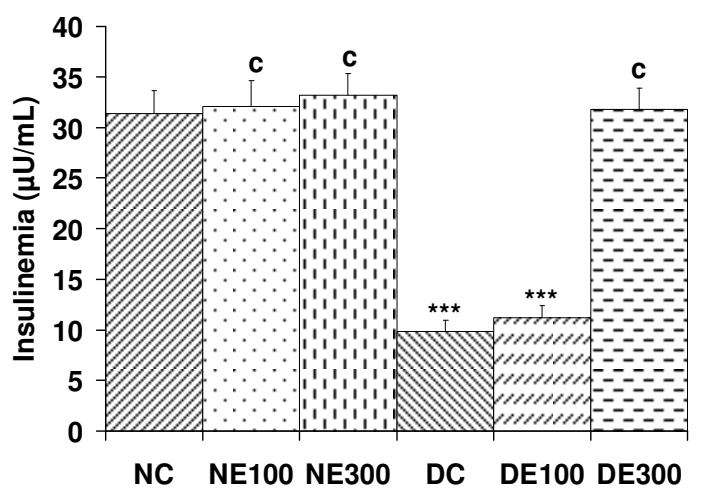

Figure 3: Plasma insulin level after 15 days of treatment with Terminalia glaucescens leaf extract. Key: $100 \mathrm{mg} \mathrm{kg}^{-1}$ body weight in normal mice (NE100) and in diabetic mice (DE100), $300 \mathrm{mg} \mathrm{kg}^{-1}$ body weight in normal (NE300) and diabetic mice (DE300) mice; normal mice (NC) and diabetic mice (DC) control groups treated with vehicle.

Data are mean \pm S.E.M., $n=8$. Significant difference: ${ }^{* \star *} \mathrm{P}<0.001$ compared with NC value; ${ }^{\mathrm{C}} \mathrm{P}<0.001$ compared with $\mathrm{DC}$ value.

Table 1: Plasma lipid (triglycerids TG, non esterified fatty acids NEFA, cholesterol) levels $(\mathrm{mmol} / \mathrm{L})$ after 15 days treatment with Terminalia glaucescens leaf extract. Key: $100 \mathrm{mg} \mathrm{kg}^{-1}$ body weight in normal mice (NE100) and in diabetic mice (DE100); , $300 \mathrm{mg} \mathrm{kg}^{-1}$ body weight in normal mice (NE300) and in diabetic mice (DE300); normal mice (NC) and diabetic control (DC) control groups treated with vehicles.

\begin{tabular}{lllllll} 
& NC & NE100 & NE300 & DC & DE100 & DE300 \\
\hline \multirow{2}{*}{ TG } & $0.889 \pm$ & $0.941 \pm$ & $0.871 \pm$ & $1.407 \pm$ & $1.292 \pm$ & $1.022 \pm$ \\
& 0.040 & $0.060^{\mathrm{a}}$ & $0.060^{\mathrm{a}}$ & $0.185^{\star}$ & $0.162^{\star}$ & $0.032^{\star_{\mathrm{a}}}$ \\
& & & & & & \\
NEFA & $0.321 \pm$ & $0.293 \square$ & $0.273 \pm$ & $0.413^{\star} \pm$ & $0.355 \pm$ & $0.303 \pm$ \\
& 0.037 & $0.035^{\mathrm{a}}$ & $0.016^{\mathrm{b}}$ & $0.041^{\star}$ & 0.039 & 0.044
\end{tabular}

Results are mean \pm S.E.M., $(n=8)$. Significant differences: $P<0.05$ compared with NC values; ${ }^{\mathrm{a}} \mathrm{P}<0.05,{ }^{\mathrm{b}} \mathrm{P}<0.01$ and ${ }^{\mathrm{c}} \mathrm{P}<0.001$ compared with $\mathrm{DC}$ values. 


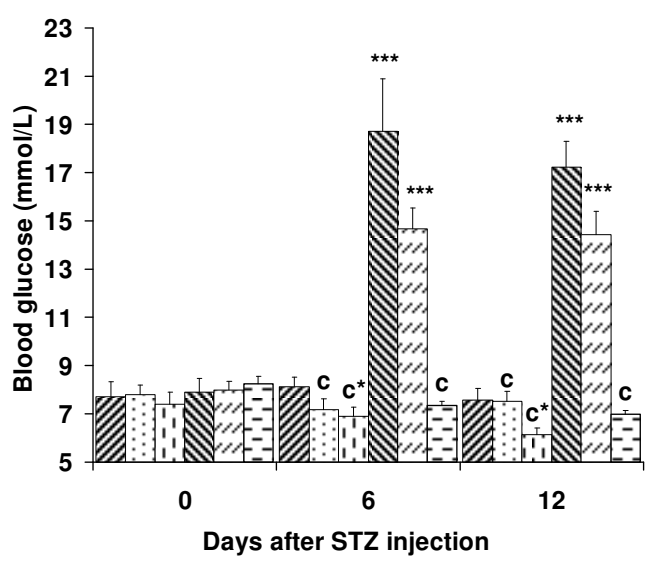

Figure 4: Blood glucose level within 12 days of treatment with Terminalia glaucescens leaf

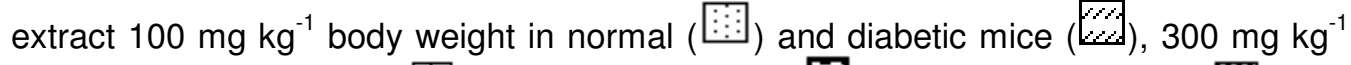

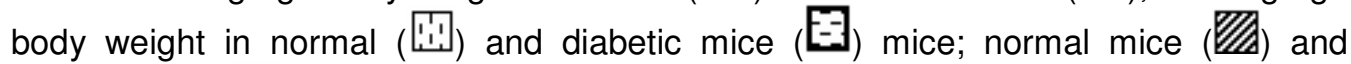
diabetic mice (-) control groups treated with vehicle.

Data are mean \pm S.E.M., $n=8$. Significant difference: ${ }^{*} \mathrm{P}<0.05$ and ${ }^{* * *} \mathrm{P}<0.001$ compared with NC values; ${ }^{C} \mathrm{P}<0.001$ compared with $\mathrm{DC}$ values.

effect in mice which had STZ-induced hyperglycemia, but there was a significant fall in blood glucose in DE300 mice to the extent that glycemia was comparable to NC mice. In normal mice, $T$. glaucescens treatment resulted in a decrease of blood glucose levels $(-9 \%)$ in a dose-dependent manner in NE300 $(\mathrm{P}<0.05)$.

\section{DISCUSSION}

This study was carried out to assess the protective effect of the methanol/methylene chloride extract of Terminalia glaucescens leaf on impaired glucose level induced by STZ. Our results show that intraperitoneal administration of multiple doses of STZ (45 $\mathrm{mg} \mathrm{kg}^{-1}$ for 5 consecutive days) effectively induced diabetes in normal fasted mice as reflected by hyperglycemia, polyphagia, polydipsia and body weight loss, compared with normal control (NC) mice.

The $T$. glaucescens extract dose of $300 \mathrm{mg}$ $\mathrm{kg}^{-1}$ body weight significantly inhibited the hyperglycemic action of STZ, while the blood glucose level of diabetic control was distinctly increased $(+117 \%)$. Streptozotocin induces hyperglycemia by selective destruction of pancreatic $\square$-cells that secrete insulin ${ }^{9,15}$. This suggests that the extract $\left(300 \mathrm{mg} \mathrm{kg}^{-1}\right)$ may prevent decreased insulin secretion by protecting $\square$-cells against destruction caused by STZ.

In the extract-pretreated mice, diabetic manifestations after STZ administration were reduced, suggesting that the extract may involve direct inhibition of STZ. The extract may act by competing with STZ for glucose associated-receptors on $\square$-cell membranes. A phytochemical analysis of $T$. glaucescens has revealed the presence of tannin, alkaloids, flavonoids, triterpenoids and glucose ${ }^{16}$. The anti-hyperglycemic activity of $T$. glaucescens may be due to any one or more of these constituents in the extract. STZ is a 2-desoxyD-glucose derivative of $\mathrm{N}$-methyl-N-nitrosourea $^{17,18}$. Thus, it is possible that the glucose moiety of STZ, which can bind to glucose 
receptors on $\square$-cells, may directly compete with the glucose contained in the extract ${ }^{19}$.

T. glaucescens extract might also have acted by increasing the resistance of $\square$-cells by a direct activation of superoxide dismutase, a widely distributed enzyme that scavenges superoxide anion radical which may be responsible for the toxic effects of $S T Z^{20,21}$. The secretion of insulin correlated with the reduction of glycemia. Moreover, $T$. glaucescens extract in normal mice and 300 $\mathrm{mg} \mathrm{kg}^{-1}$ extract in diabetic test mice did not increase insulinemia beyond the normal control value. This suggests that in diabetes, $T$. glaucescens sensitizes insulin peripheral action rather than stimulating insulin secretion. $T$. glaucescens probably lowers blood lipids (TG, NEFA, cholesterol) due to improvement of peripheral insulin action, while body weight loss as well as increase in food consumption and the related water intake result from the lack of insulin action.

The present study showed high plasma NEFA in diabetic mice. Excess plasma NEFA can inhibit insulin-stimulated glucose utilization in muscle and promote hepatic production of glucose $^{22,23}$, whereas reduction of plasma NEFA concentration improves glucose utilization and the suppression of hepatic glucose production by insulin ${ }^{24,25}$. The reduction of plasma NEFA may also explain the anti-hyperglycemia effect of $T$. glaucescens extract.

\section{CONCLUSION}

The results from this study indicate that $T$. glaucescens extract in STZ-induced diabetes could have protective effects. The antihyperglycemia effect of $T$. glaucescens extract in STZ-induced diabetes could explain the traditional use of this plant for diabetes treatment or management. Further studies are required to elucidate the site(s), as well as cellular and molecular mechanism of actions of $T$. glaucescens extract.

\section{REFERENCES}

1 Kameswara Rao B, Renuka Sudarshan P, Rajasekhar MD, Nagaraju N, Appa Rao Ch. Antidiabetic activity of Terminalia pallida fruit in alloxan-induced diabetic rats. J Ethnopharmacol, 2003; 85:169-172.

2 Foulis AK. The pathogenesis of $\square$-cells destruction in type1 (insulin-dependent) diabetes mellitus. J Pathol, 1987; 152:141-148.

3 Gepts W, Le Compte PM. The pathology of type I (juvenile) diabetes, in: Body weight yolk, E.R.Arquilla (Eds), The Diabetic pancreas. Plenum N, 1985, pp337-365.

4 Takamura $T$, Ando H, Nagai $Y$, Yamashita H, Nohara E, Kobayashi K. Pioglitazone prevents mice from multiple low dose streptozotocin -induced insulitis and diabetes. Diab Res Clin Pract, 1999; 44:107114.

5 Burcelin R, Eddouks M, Maury J, Kande J, Assan R, Girard J. Excessive glucose production, rather than insulin resistance, accounts for hyperglycemia in recent-onset streptozotocin-diabetic rats. Diabetologia, 1995; 38:283-290.

6 Kameswara B, Kesavulu MM, Apparao C. Antihyperglycemia activity of Momordica cymbalaria in alloxan diabetics rats. J Ethnopharmacol, 2001; 78:67-71.

7 Kamtchouing P, Kahpui SM, Djomeni Dzeufiet $P-D$, Tédong L, Asongalem EA, Dimo T. Anti-diabetic activity of methanol/methylene chloride stem bark extracts of Terminalia superba and Canarium schweinfurthii on streptozotocin-induced diabetic rats. J Ethnopharmacol, 2006; 104:306-309.

8 Luo J, Fort DM, Carlson TJ. Cryptolepis sanguinolenta: an ethnobotanical approach to drug discovery and the isolation of potentially useful new antihyperglycemia agent. Diabetic Med, 1998; 15:367374.

9 Zheng J, He J, Ji B, Li Y, Zhang X. Anti-hyperglycemia activity of Prunella vulgaris $L$. in streptozotocininduced diabetic mice. Asia Pac J Clin Nutr, 2007; 16(Suppl 1):427-431.

10 Mukherjee SK. Indigenous drugs in diabetes mellitus. J Diab Assoc Ind, 1981; 21:97-106

11 Nalamolu Koteswara Rao and Srinivas Nammi. Antidiabetic and renoprotective effects of the chloroform extract of Terminalia chebula Retz seeds in streptozotocin-induced diabetic rats. BMC Complement Altern Med, 2006; 6:17.

12 Rai MK. A review on some antidiabetic plants of india. Ancient Sci Life, (1995) 14:42-54.

13 Tsvia P, Barak AT, Israel S. Clioquinol attenuates zincdependent $\beta$-cell death and the onset of insulitis and hyperglycemia associated with experimental type I diabetes in mice. Eur J Pharmacol, 2007; 565:232239.

14 Ji-Youn Youn, Hyo-Young Park and Kyung-Hea Cho. Anti-hyperglycemic activity of Commelina communis 
Kamgang et al

L.: inhibition of $\alpha$-glucosidase. Diab Res Clin Pract, 2004; 66(suppl.1):149-155

15 Ojewole JAO, Drewes SE. Hypoglycemia effect of Eriosema kraussianum N. E. Br. [Fabaceae] rootstock hydro-alcohol extract in rats. J Nat Med, 2007; 61:244-250.

16 Atta-ur-Rahman, Seema Zareen, Choudhary MI, Akhtar MN, Shahida Shujaat, Ngounou FN. Some chemical constituents of Terminalia glaucescens and their enzyme inhibition activity. Zeitschrift für Naturforschung. B, Chemical Sciences, 2005; 60(2):347-350.

17 Reusser F.. Mode of action of streptozotocin. $J$ Bacteriol, 1971; 105:580-588.

18 Szkudelski T. The mechanism of alloxan and streptozotocin action in $\square$-cells of the rat pancreas. Physiol Res, 2001; 50:536-546.

19 Crouch R, Kimsey G, Priest DG, Sarda A, Buse MG. Effect of streptozotocin on erythrocyte and retinal superoxide dismutase. Diabetologia, 1978; 15:53-57.

20 Robbins MJ, Sharp RA, Slonium AE, Burr IM. Protection against streptozotocin-induced diabetes by superoxide dismutase. Diabetologia, 1980; 18:5558.

21 Sandler S, Andersson A. The partial protective effect of the hydroxyl radical scavenger dimethyl urea on streptozotocin-induced diabetes in the mouse in vivo and in vitro. Diabetologia, 1982; 23:374-378.

22 Roden M, Price TB, Perseghin G, Petersen KF, Rothman DL, Cline GW, Shulman Gl. Mechanism of free fatty acid-induced insulin resistance in humans. $J$ Clin Invest, 1996; 97:2859-2865.

23 Boden G, Chen X, lqbal N. Acute lowering of plasma fatty acids lowers basal insulin secretion in diabetic and nondiabetic subjects. Diabetes, 1998; 47:16091612.

24 Reaven GM, Chang $H$, Ho H, Jeng CY, Hoffman BB. Lowering of plasma glucose in diabetic rats by antilipolitic agents. Am J Physiol, 1988; 254:E23E30.

25 Saloranta C, Fransilla-Kallunki $A$, Ekstrand $A$, Taskinen MR, Groop L. Modulation of hepatic glucose production by non-esterified fatty acids in type 2 (non-insulin-dependent) diabetes mellitus. Diabetologia, 1991; 34:409-415. 